\title{
Association of Flavobacterium psychrophilum strains with intestinal explants of rainbow trout Oncorhynchus mykiss
}

\author{
Amin Nematollahi ${ }^{1,3, *}$, Frank Pasmans ${ }^{1}$, Wim Van den Broeck ${ }^{2}$, Richard Ducatelle ${ }^{1}$, \\ Freddy Haesebrouck ${ }^{1}$, Annemie Decostere ${ }^{1}$
}

\author{
${ }^{1}$ Department of Pathology, Bacteriology and Avian Diseases, and ${ }^{2}$ Department of Morphology, \\ Faculty of Veterinary Medicine, Ghent University, Salisburylaan 133, 9820 Merelbeke, Belgium \\ ${ }^{3}$ Department of Food Hygiene and Quality Control, Faculty of Veterinary Medicine, Shahrekord University, Saman Road, \\ PO Box 115, Shahrekord, Iran
}

\begin{abstract}
Flavobacterium psychrophilum is an important pathogen in rainbow trout Oncorhynchus mykiss. The portal of entry for F. psychrophilum is not well known. In this study, the role of the intestine as a colonization site for F. psychrophilum was determined. For this purpose, the ability of a high (Dubois) and a low (99/10A) virulence strain of F. psychrophilum to adhere to intestinal explants of rainbow trout was evaluated. After incubation, samples of the gut were examined bacteriologically, histologically and by electron microscopy. The number of gut-associated F. psychrophilum bacteria was significantly higher for the Dubois than for the 99/10A strain. Histological samples clearly showed numerous bacteria of the high virulence strain associated with the intestinal tissue as opposed to only a few bacteria of the low virulence strain. Additionally, extensive exfoliation of intestinal epithelium was noted after incubation with the high virulence strain, but less with the low virulence strain. These findings were confirmed using scanning electron microscopy and suggest that the intestinal epithelium might represent an important site for colonization of the $F$. psychrophilum strain and may act as a portal of entry for high virulence F. psychrophilum.
\end{abstract}

KEY WORDS: Flavobacterium psychrophilum · Rainbow trout · Intestinal explant · Colonization

\section{INTRODUCTION}

Flavobacterium psychrophilum (formerly Cytophaga psychrophila/Flexibacter psychrophilus) is a Gramnegative and slender rod-shaped bacterium belonging to the family Flavobacteriaceae (Bernardet et al. 1996). It is an important fish pathogen which causes bacterial cold water disease (BCWD) in adult salmonids and rainbow trout fry syndrome (RTFS) in fry (Bruno 1992, Holt et al. 1993, Austin \& Austin 1999). The latter is recognized as a serious bacterial disease affecting hatchery-reared rainbow trout Oncorhynchus mykiss, fry and fingerlings world-wide. RTFS accounts for 10 to $30 \%$ of mortality in farmed rainbow trout (Bruno 1992), sometimes as much as $70 \%$ (Chua 1991). To date, little information is available about the pathogenesis of F. psychrophilum infections (Rangdale 1995, Lorenzen et al. 1997, Nematollahi et al. 2003a).

Mode of transmission as well as the portal of entry for Flavobacterium psychrophilum into the host's body still need to be elucidated (Lorenzen 1994, Rangdale 1995, Nematollahi et al. 2003a). The pathogen may enter the fish's body through either the skin, the gills or the gastrointestinal tract (Ellis 2001). Interactions with the gill tissue have been described previously (Nematollahi et al. 2003b). Lorenzen (1994), and Liu et al. (2001) demonstrated the presence of F. psychrophilum in the lumen and (sub)mucosa of the stomach and intestine of naturally infected rainbow trout fry and ayu Plecoglossus altivelis, pointing towards the 
involvement of the gastrointestinal tract as a portal of entry. Nevertheless, using both the oral and anal inoculation route, Decostere et al. (2000) were not able to reproduce the disease experimentally. The role of the intestine as a suitable colonization site for the bacterium is hence unclear.

Several studies mention differences in the association of Flavobacterium psychrophilum strains with rainbow trout cells (Rangdale 1995, Møller et al. 2003, Nematollahi et al. 2003b, Wiklund \& Dalsgaard 2003). It remains obscure, however, whether these differences also occur in the trout intestine. The purpose of the present study was to investigate whether the intestine can be a colonization site for the bacterium using intestinal explants.

\section{MATERIALS AND METHODS}

Fish. Eighteen rainbow trout Oncorhynchus mykiss of $500 \mathrm{~g}$ average weight were obtained from a commercial fish farm (Dilbeek, Belgium) with no history of RTFS or BCWD. The fish were kept in a flow through system (2000 l tank) containing aerated well water $\left(16\right.$ to $\left.18^{\circ} \mathrm{C}\right)$ for $3 \mathrm{wk}$ prior to experimentation $(\mathrm{pH} 7.6$; total hardness $100 \mathrm{ppm} ; \mathrm{NH}_{3}<0.01 \mathrm{ppm} ; \mathrm{NO}_{2}<$ $0.01 \mathrm{ppm}$; dissolved oxygen $9 \mathrm{ppm}$ ). The fish were fed daily with a commercial diet (Trouvit Perle Response 2000, Trouw). All fish were clinically examined prior to experimentation. To make sure no parasitic infestations were present, samples were taken from the skin and gills. The presence of Flavobacterium psychrophilum was assessed by streaking swabs from the skin, gills and fins onto Shieh agar (Shieh 1980). Plates were incubated at $17^{\circ} \mathrm{C}$ for $5 \mathrm{~d}$. The fish were found to be free of external parasite infestations and F. psychrophilum was not isolated from any of the collected samples.

Bacterial strains and culture conditions. Two Flavobacterium psychrophilum strains were used: Strain 99/10A and Strain Dubois. Strain 99/10A was recovered from the kidney of rainbow trout in Denmark (Wilkund \& Dalsgaard 2003). Strain Dubois was isolated from the spleen in an outbreak of RTFS in Belgium with high mortality (70\%) among the affected rainbow trout fry. In order to preserve virulent properties, both strains were stored virtually immediately following in vivo isolation at $-70^{\circ} \mathrm{C}$. Experimental infection studies using intraperitoneal injection proved that Strain Dubois was a high virulence strain whereas Strain 99/10A was found to be of low virulence (Madsen \& Dalsgaard 1998, Decostere et al. 2001).

Stock suspensions of the 2 strains were stored at $-70^{\circ} \mathrm{C}$. After thawing, the bacteria were grown for $4 \mathrm{~d}$ in $4 \mathrm{ml}$ of Shieh broth at $17^{\circ} \mathrm{C}$. Subsequently, sub- cultures were incubated for $4 \mathrm{~d}$ at $17^{\circ} \mathrm{C}$. The cultured broth was centrifuged $\left(3000 \times g, 10 \mathrm{~min}, 17^{\circ} \mathrm{C}\right)$ and the resulting pellet and supernatant were separated. The pellet was re-suspended in phosphate-buffered saline (PBS), pH 7.2, and the number of colony forming units (CFU) was determined by plating 10-fold serial dilutions on Shieh agar plates.

Experimental design. The model system used has been previously described (Nematollahi et al. 2005). Briefly, fish were anaesthetised using a benzocaine solution in ethanol (w/v: $0.1 \mathrm{~g} \mathrm{ml}^{-1}$ ), injected intraperitoneally with heparin (5000 IU kg-1) (Leo Pharmaceutical Products) and allowed to recover. After $30 \mathrm{~min}$, the fish were killed using an overdose of the benzocaine solution and the abdomen of the fish was opened laterally. The intestine of rainbow trout is supplied by 2 main blood vessels, namely the aorta intestinalis dorsalis and the aorta intestinalis ventralis (Thorazensen et al. 1991, Stoskopf 1993). The larger vessel, the aorta intestinalis ventralis, was cannulated with a Surflo IV cannula (Terumo Europe N.V.), which was tied up with a ligature (silk 2/0) using a surgical knot. Both the cranial and caudal end of the gut were severed and the gut was placed in a Petri dish containing Ringer solution. Subsequently, the gut was gently flushed with 10 $\mathrm{ml}$ PBS and a ligature was tied around the cranial end. The gut segment was suspended in an aerated organ bath at $12^{\circ} \mathrm{C}$ which was filled with Ringer solution (volume $=200 \mathrm{ml}$ ) and perfusion was started. A drip, filled with $1500 \mathrm{ml}$ of the perfusion fluid and set at approximately $60 \mathrm{~cm}$ above the bath, was used. Filtered (Corning, $0.45 \mu \mathrm{m}$ ) and heparinized (10 $\mathrm{IU} \mathrm{ml}^{-1}$ ) Cortland + dextran 1\% (MW 500000; Sigma) was used as perfusion fluid. Dissection, cannulation, rinsage, injection and ligature of each gut segment were carried out within $15 \mathrm{~min}$.

For inoculation, $0.5 \mathrm{ml}$ of bacterial suspension containing $10^{8} \mathrm{CFU}$ of either the high (Dubois) or low (99/10A) virulence Flavobacterium psychrophilum strain was injected inside the gut lumen via the caudal end and tied off. A gut segment injected with $0.5 \mathrm{ml}$ PBS served as negative control. The gut segments were each placed in separate organ baths with Ringer solution + gentamicin $\left(10 \mu \mathrm{g} \mathrm{ml}^{-1}\right)$ for killing bacteria adhering to the serosa, and incubated at $12^{\circ} \mathrm{C}$ for $60 \mathrm{~min}$. After the incubation period, each gut segment was rinsed 2 times in PBS and the ligatures were removed. Subsequently, the segments were flushed with $10 \mathrm{ml}$ PBS and processed for bacteriological, histological and electron microscopical examinations as described below. For each inoculum (either Dubois, 99/10A or PBS), the ligated intestine of 1 fish was used and the experiment was repeated twice.

Processing of the gut for bacteriological examination. For bacteriological examination, 9 fish were euth- 
anized, and the intestine removed and inoculated as described above. After incubation, half of the intestinal explant was then placed into pre-weighed vials containing $2 \mathrm{ml}$ of sterile PBS, cut into small pieces with sterile scissors and macerated. Fifty $\mu l$ of 10 -fold serial dilutions of the gut slurry were plated on Shieh agar plates in triplicate. After $5 \mathrm{~d}$ of incubation at $17^{\circ} \mathrm{C}$, viable counts were made $\left(\mathrm{CFU} \mathrm{g}^{-1}\right)$.

Processing of the gut for histological and electron microscopical examinations. The experiment was carried out as described above. Nine fish were euthanized and the intestine removed. After incubation, each gut segment was cut into 2 equally sized pieces, 1 for histological and 1 for electron microscopical examination. For histological examination, the samples of the gut were placed in $4 \%$ phosphate-buffered formaldehyde for $24 \mathrm{~h}$, sectioned and stained with Giemsa or haematoxylin-eosin (H\&E) and examined under a light microscope.

For scanning electron microscopical (SEM) examination, samples were fixed in hydroxyethyl-piperazineethanesulfonic acid (HEPES) buffer (0.1 M, pH 7.3) containing $2.5 \%$ glutaraldehyde and $2 \%$ paraformaldehyde and postfixed in $1 \%$ (w/v) osmium tetroxide in distilled water. Then, they were dehydrated in alcohol and acetone for subsequent critical point drying in liquid carbon dioxide (Balzer CPD, 030), glued with carbon cement on aluminium stubs, sputtered with a platina layer (JEOL, JFC-1300) and examined in a JSM 5600 LV scanning electron microscope (JEOL).

Statistical analysis. The results obtained with the low and high virulence strain were compared using the paired $t$-test (computer program Sigma Stat, Analytical Software). In all analyses, a value of $p<0.05$ was considered statistically significant.

\section{RESULTS}

Expressed as mean bacterial counts $( \pm \mathrm{SD})$, the bacteriological titrations showed that $7.27( \pm 0.28)$ and 5.71 $( \pm 0.20) \log _{10} \mathrm{CFU} \mathrm{g}^{-1}$ of gut tissue were recovered from intestinal explants of rainbow trout after inoculation with Flavobacterium psychrophilum strains Dubois and 99/10A, respectively. Significantly more bacteria were recovered from the gut tissue exposed to the high virulence strain than from samples inoculated with the low virulence strain $(\mathrm{p}<0.05)$. In control gut sections, no F. psychrophilum bacteria were found.

Histological examination of gut segments inoculated with the high virulence strain (Dubois) showed clusters of long and slender bacteria associated with the gut epithelium (Fig. 1A). There was also extensive sloughing of the surface epithelium and necrotic cells packed with numerous clusters of bacteria (Fig. 1B). In sections

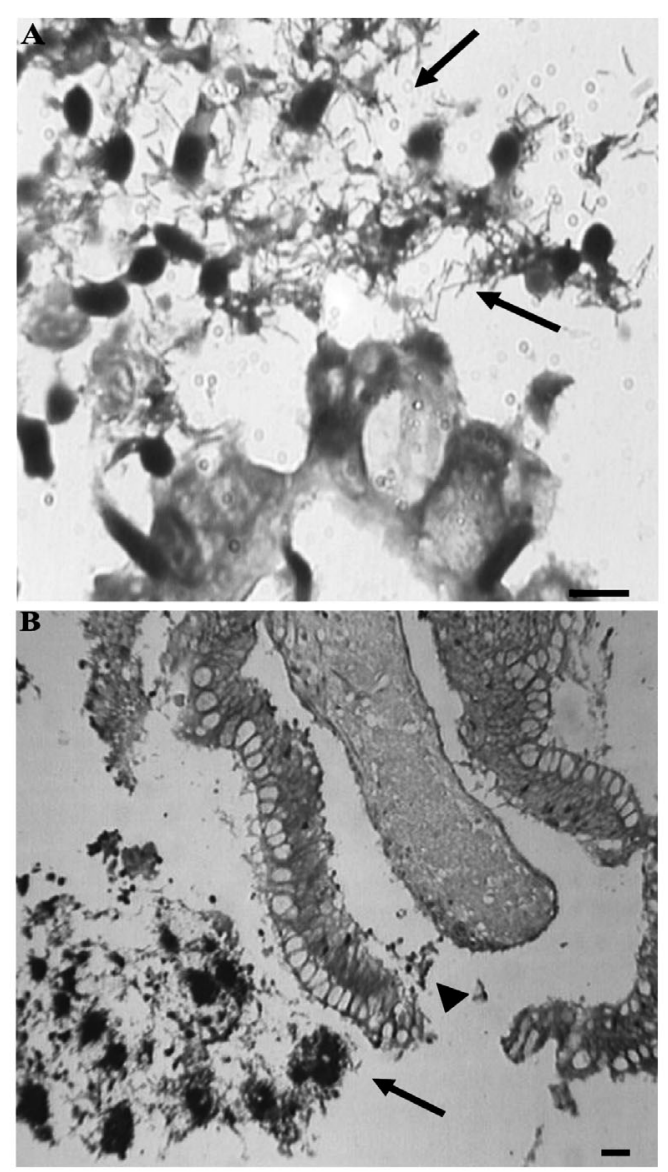

Fig. 1. Oncorhynchus mykiss. Histological section of an intestinal explant inoculated with the high virulence Flavobacterium psychrophilum Dubois strain. (A) Clusters of bacteria are associated with the gut epithelium (arrows) (scale bar $=10 \mu \mathrm{m}$, Giemsa). (B) Note the sloughing of the surface epithelium (arrowhead) and necrotic tissue (arrow) (scale bar $=50 \mu \mathrm{m}$, Giemsa)

of gut segments exposed to the low virulence strain (99/10A) only occasionally could any filamentous bacteria be observed in association with the gut epithelium. Exfoliation of epithelium was rarely observed. In control gut sections, no bacteria were noted. Indeed, the histological sections of intestinal explants either inoculated with Strain 99/10A or PBS (control) revealed the intact gut epithelium, brush border, goblet cells and slight oedema (Fig. 2).

Results of the SEM examination are shown in Figs. 3 $\& 4$. Both strains were able to adhere to the mucus layer and intestinal epithelium. Gut tissue inoculated with the high virulence strain was covered by a thick mat consisting of clusters of bacteria, mucus (Fig. 3A) and necrotic cells (Fig. 3B). In samples inoculated with the low virulence strain, markedly less bacteria were associated with the gut tissue. Additionally, the gut segments exposed to the low virulence strain were 

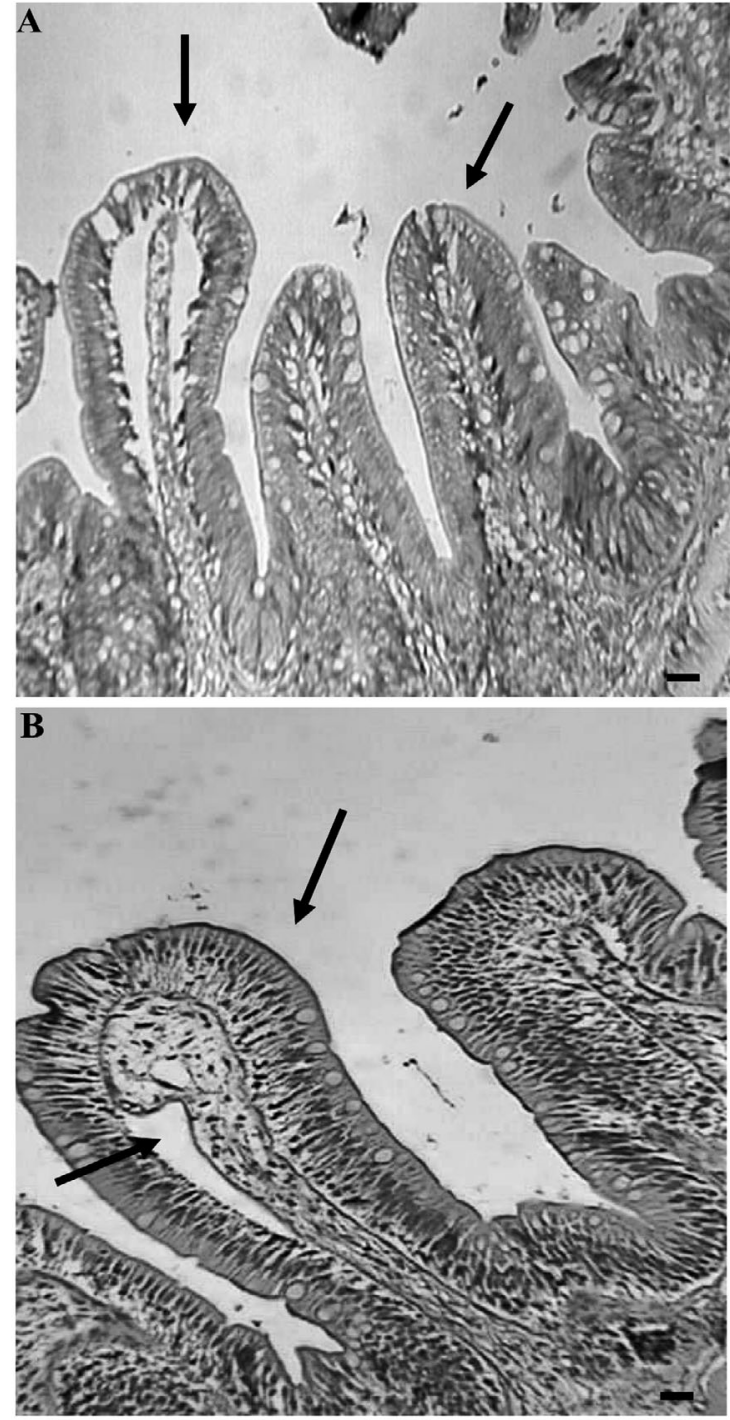

Fig. 2. Oncorhynchus mykiss. Histological section of an intestinal explant either inoculated with $(\mathrm{A})$ the low virulence Flavobacterium psychrophilum 99/10A strain or (B) PBS (control tissue). Note the intact gut tissue, brush border and epithelium and slight oedema (arrows). (A) Scale bar $=50 \mu \mathrm{m}$, Giemsa; (B) scale bar $=50 \mu \mathrm{m}, \mathrm{H} \& \mathrm{E}$

damaged far less compared to samples challenged with the high virulence strain (Fig. 4A). Indeed, the intestinal tissue of the control gut sections remained intact during the incubation period (Fig. 4B).

\section{DISCUSSION}

The basic steps in the establishment of an infection by a bacterial pathogen include attachment or entry into the host's body, evasion of host defences against infection, multiplication at the site of infection, damage
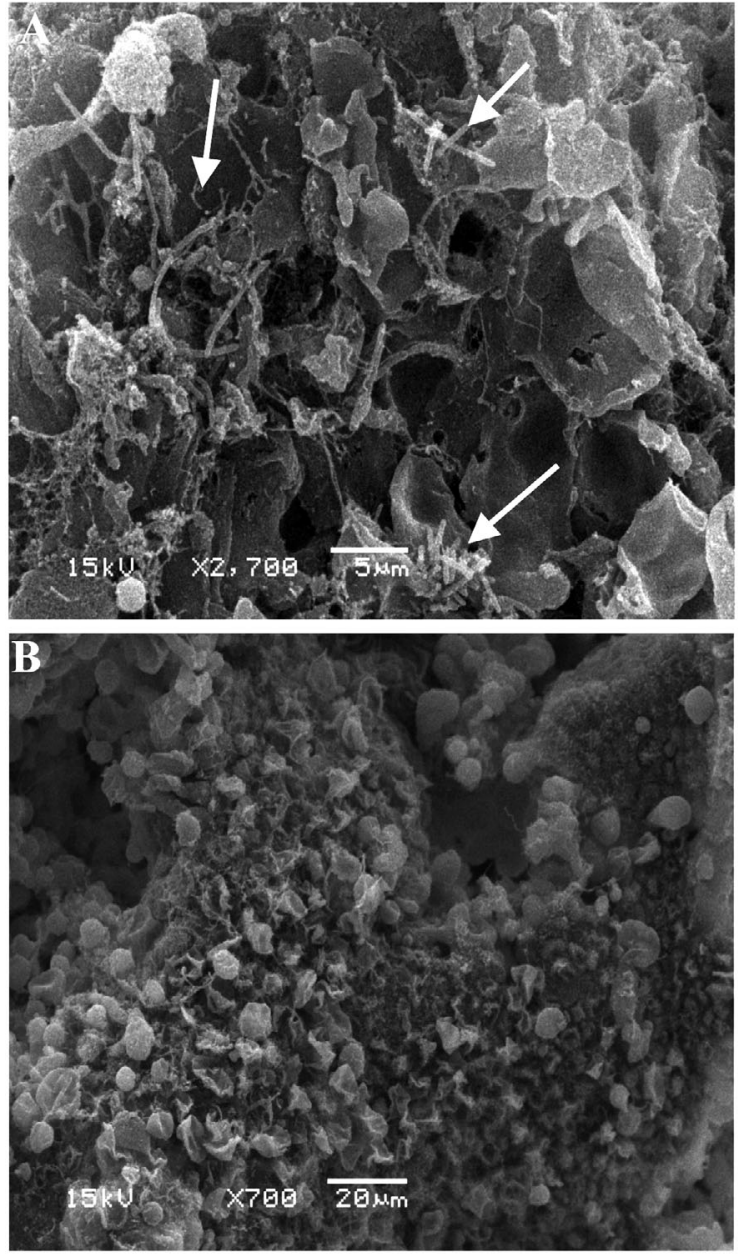

Fig. 3. Oncorhynchus mykiss. Scanning electron microscopy of an intestinal explant, inoculated with the high virulence Flavobacterium psychrophilum Dubois strain. (A) Surface is covered with an irregular mat consisting of clusters of bacteria (arrows), exfoliated epithelial cells and mucus. Note the extensive desquamation of intestinal epithelial cells (scale bar $=5 \mu \mathrm{m}$ ). (B) Severe epithelial damage of the intestine with necrotic cells in process of exfoliation (scale bar $=20 \mu \mathrm{m}$ )

to the host tissues and transmission from the infected animal to other susceptible animals (Gyles \& Prescott 2004). In this study, the possible role of the gut of rainbow trout as a colonization site for Flavobacterium psychrophilum was determined. Several authors have attempted to set up a cohabitation and contact/immersion infection model in an attempt to mimic the natural route of infection. This was performed successfully by Rangdale (1995), Madsen \& Dalsgaard (1999), Madetoja et al. (2000), but only after stressing the fish. However, other researchers failed to reproduce the disease in fish through immersion challenges and oral inoculation (Mudarris \& Austin 1989, Iida \& Mizokami 1996, Ostland et al. 1997, Decostere et al. 2000). As far as oral inoculation is concerned, the low $\mathrm{pH}$ in the fish 

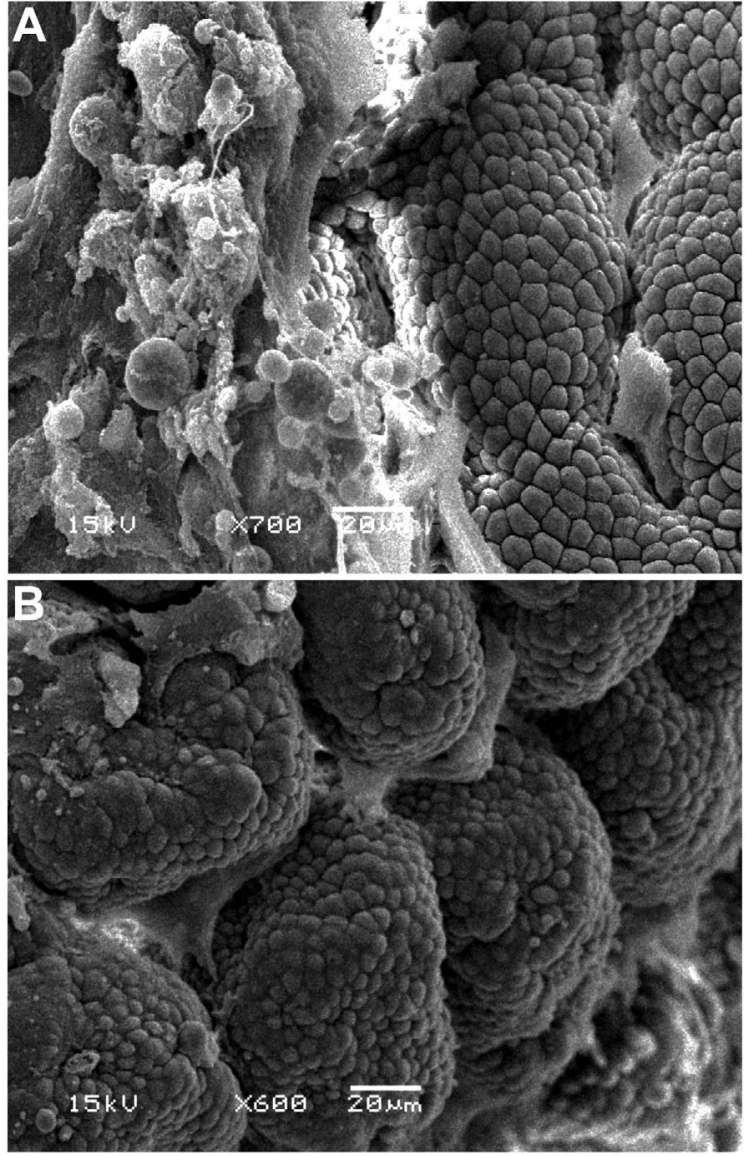

Fig. 4. Oncorhynchus mykiss. Scanning electron microscopy of an intestinal explant inoculated with (A) the low virulence Flavobacterium psychrophilum strain or (B) PBS (control tissue). (A) Area of intact epithelium beside an area of exfoliating intestinal epithelium (scale bar $=20 \mu \mathrm{m}$ ). (B) Control gut shows mucus and intact epithelial tissue (scale bar $=20 \mu \mathrm{m})$

stomach may have a negative influence on the survival of F. psychrophilum. Additionally, it is possible that the bacterium was inactivated by the presence of digestive enzymes in the gastrointestinal tract (Decostere et al. 2000).

The gut perfusion model used in this study mimics the in vivo situation and overcomes some difficulties of in vivo infection experiments by bypassing the stomach but maintaining the anatomic intestinal integrity. This enables the study of the interaction of Flavobacterium psychrophilum with a specific part of the digestive tract under controllable conditions. The advantage of the model used over in vitro techniques (e.g. cell cultures) is the integrity of the epithelial barrier, including the mucus layer (Nematollahi et al. 2005).

The resulting data prove that the high virulence Dubois strain has more ability to adhere to the gut tissue than the low virulence 99/10A strain as demon- strated by histology, SEM and bacteriology counts. This might indicate that the high virulence strain has a higher intestinal colonization capacity than the low virulence strain. This hypothesis is in line with a previous report in which a positive correlation between bacterial virulence and the ability to adhere to piscine epithelial cells in vitro was found (Del Corral 1975). Zaldiver (1985) and Del Corral (1999) correlated the virulence of Flavobacterium columnare and Aeromonas hydrophila strains and their ability to adhere to epithelial cells in vitro.

As a whole, the intestinal explants exposed to the low virulence strain were in a much better condition than those inoculated with the high virulence strain as shown by histology and SEM. The high virulence strain induced sloughing of the surface epithelium, clumping of the epithelial cells which in some areas led to severe tissue necrosis. This correlates well with the observation of intestinal damage in natural outbreaks of RTFS (Lorenzen 1994). Bacteria were seen attached to either mucus or epithelial cells. Adherence of bacteria to mucus suggests that mucus can provide an important site of colonization in the fish intestine. In addition, intestinal mucus provides a rich source of nutrients that allows the bacteria to multiply (Krivan et al. 1992, Ellis 2001). Attachment to and penetration into intestinal mucus and epithelial cells are also important in the colonization of fish intestine by other fish bacteria (Austin \& Austin 1999, Roberts 2001). Interestingly, the results of the present experiment correlate with those of similar experiments with Flavobacterium psychrophilum and gill tissue (Nematollahi et al. 2003b).

In conclusion, these results suggest that adhesion to the gut might represent an important site for successful colonization of Flavobacterium psychrophilum.

Acknowledgements. We thank Dr. I. Dalsgaard (Danish Institute for Fisheries Research, Denmark) and Dr. F. Lieffrig (Centre d' Economie Rurale, Marloie, Belgium) for providing the Flavobacterium psychrophilum strains. Mr. C. Puttevils and Mr. B. De Pauw are acknowledged for their excellent technical assistance. The Ministry of Science, Research and Technology of Iran is thanked for providing a scholarship to A.N.

\section{LITERATURE CITED}

Austin B, Austin DA (1999) Bacterial fish pathogens: disease of farmed and wild fish. Praxis Publishing, Chichester

Bernardet JF, Sergers P, Vancanneyt M, Berthe F, Kersters K, Vandamme P (1996) Cutting a Gordian knot: emended classification and description of the genus Flavobacterium, emended description of the family Flavobacteriaceae, and proposal of Flavobacterium hydatis nom. nov. (Basonym, Cytophaga aquatilis Strohl and Tait 1978). Int J Syst Bacteriol 46:128-148 
Bruno DW (1992) Cytophaga psychrophila (= Flexibacter psychrophilus) (Borg), histopathology associated with mortalities among farmed rainbow trout, Oncorhynchus mykiss (Walbaum) in the UK. Bull Eur Assoc Fish Pathol 12: $215-216$

Chua FHC (1991) A study on the rainbow trout fry syndrome. MSc thesis, University of Stirling

Decostere A, Lammens M, Haesebrouck F (2000) Difficulties in experimental infection with Flavobacterium psychrophilum in rainbow trout (Oncorhynchus mykiss) using immersion, oral and anal challenges. Res Vet Sci 69: 165-169

Decostere A, D'Haese E, Lammens M, Nelis H, Haesebrouck F (2001) In vivo study of phagocytosis, intracellular survival and multiplication of Flavobacterium psychrophilum in rainbow trout, Oncorhynchus mykiss (Walbaum), spleen phagocytes. J Fish Dis 24:481-487

Del Corral F (1975) Virulence properties of selected bacterial fish pathogens. PhD thesis, University of Georgia, Athens, GA

Del Corral F, Shotts EB, Brown J (1999) Adherence, haemagglutination and cell surface characteristics of motile aeromonads virulent for fish. J Fish Dis 13:255-268

Ellis AE (2001) The immunology of teleosts. In: Roberts RJ (ed) Fish pathology. Harcourt Publisher Limited, London, p 133-150

Gyles CL, Prescott JF (2004) Themes in bacterial pathogenic mechanisms. In: Gyles CL, Prescott JF, Songer JG, Thoen CO (eds) Pathogenesis of bacterial infections in animals. Blackwell Scientific, Oxford, p 3-13

Holt RA, Rohevec JS, Fryer JL (1993) Bacterial coldwater disease. In: Inglis V, Roberts RJ, Bromage NR (eds) Bacterial diseases of fish. Blackwell Scientific, Oxford, p 3-23

Iida Y, Mizokami A (1996) Outbreaks of coldwater disease in wild ayu and chub. Fish Pathol 31:157-164

Krivan HC, Franklin DP, Wang WT, Laux DC, Cohen PS (1992) Phosphatidylserine found in intestinal mucus serves as sole source of carbon and nitrogen for salmonellae and Escherichia coli. Infect Immun 60:3943-3946

Liu H, Izumi S, Wakabayashi H (2001) Detection of Flavobacterium psychrophilum in various organs of ayu Plecoglossus altivelis by in situ hybridization. Fish Pathol 36:7-11

Lorenzen E (1994) Study on Flexibacter psychrophilus in relation to rainbow trout fry syndrome (RTFS). PhD thesis, Royal Veterinary and Agriculture University, Copenhagen

Lorenzen E, Dalsgaard I, Bernardet JF (1997) Characterization of isolates of Flavobacterium psychrophilum associated with coldwater disease or rainbow trout fry syndrome: phenotypic and genomic studies. Dis Aquat Org 31:197-208

Madetoja J, Nyman P, Wiklund T (2000) Flavobacterium psychrophilum, invasion into and shedding by rainbow trout Oncorhynchus mykiss. Dis Aquat Org 43:27-38

Editorial responsibility: David Bruno,

Aberdeen, UK
Madsen L, Dalsgaard I (1998) Characterization of Flavobacterium psychrophilum; comparison of proteolytic activity and virulence of strains isolated from rainbow trout (Oncorhynchus mykiss). In: Barnes AC, Davodson GA, Hiney MP, McIntosh D (eds) Methodology in fish diseases research. Fisheries Research Services, Aberdeen, p 45-52

Madsen L, Dalsgaard I (1999) Reproducible methods for experimental infection with Flavobacterium psychrophilum in rainbow trout Oncorhynchus mykiss. Dis Aquat Org 36:169-176

Møller JD, Larsen JL, Madsen L, Dalsgaard I (2003) Involvement of a sialic acid-binding lectin with hemagglutination and hydrophobicity of Flavobacterium psychrophilum. Appl Environ Microbiol 69:5275-5280

Mudarris M, Austin B (1989) Systemic disease in trout Scophthalmus maximus caused by a previously unrecognised Cytophaga like bacterium. Dis Aquat Org 6:161-166

Nematollahi A, Decostere A, Pasmans F, Haesebrouck F (2003a) Flavobacterium psychrophilum infections in salmonid fish. J Fish Dis 26:563-574

Nematollahi A, Decostere A, Pasmans F, Ducatelle R, Haesebrouck F (2003b) Adhesion of high and low virulence Flavobacterium psychrophilum strains to isolated gill arches of rainbow trout Oncorhynchus mykiss. Dis Aquat Org 55:101-107

Nematollahi A, Decostere A, Ducatelle R, Haesebrouck F, Pasmans F (2005) Development of a gut perfusion model as an alternative to the use of live fish. Lab Anim 39:194-199

Ostland VE, Mcgrogan DC, Ferguson HW (1997) Cephalic osteochondritis and necrotic scleritis in intensively reared salmonids associated with Flexibacter psycrophilus. J Fish Dis 20:443-450

Rangdale RE (1995) Studies on rainbow trout fry syndrome (RTFS). PhD thesis, Ministry of Agriculture, Fisheries and Food, Weymouth, University of Stirling

Roberts RJ (2001) Fish pathology, 3rd edn. Harcourt Publisher Limited, London

Shieh HS (1980) Studies on the nutrition of a fish pathogen, Flexibacter columnaris. Microbios Lett 13:129-133

Stoskopf MK (1993) Anatomy. In: Stoskopf MK (ed) Fish medicine. WB Saunders, London, p 2-31

Thorazensen H, Mclean E, Donaldson EM, Farrell AP (1991) The blood vasculature of the gasterointestinal tract in chinook, Oncorhynchus tshawytscha (Walbaum), and coho, O. kisutch (Walbaum) salmon. J Fish Biol 38:525-531

Wiklund T, Dalsgaard I (2003). Association of Flavobacterium psychrophilum with rainbow trout (Oncorhynchus mykiss) kidney phagocytes in vitro. Fish Shellfish Immunol 15: 387-395

Zaldiver M (1985) Attachment Flexibacter columnaris to fish cells. Oregon State University Sea Grant College Program, Corvallis, OR

Submitted: April 10, 2005; Accepted: August 11, 2005

Proofs received from author(s): October 31, 2005 